\title{
THE SUPERIOR CERVICAL GANGLION AND THE CERVICAL PORTION OF THE SYMPATHETIC TRUNK
}

\author{
S. W. RANSON AND P. R. BILLINGSLEY \\ From the Anatomical Laboratory of Northwestern University Medical School ${ }^{1}$ \\ FIFTEEN FIGURES
}

In this paper we shall report observations on the superior cervical ganglion and the nerves immediately associated with it. But in dealing with the literature it has been necesssary to treat the subject in a somewhat broader way and to set forth what is known concerning the sympathetic ganglia in general.

The general plan of the cephalic end of the sympathetic trunk, according to the evidence obtained by the nicotine and degeneration methods, is as follows: The trunk below the superior cervical ganglion consists of fibers ascending to end in that ganglion (fig. 1). These are preganglionic fibers, the axons of cells located in the intermediolateral cell column of the spinal cord, which have entered the trunk through the upper thoracic white rami and are ascending to the ganglion. Having reached the superior cervical ganglion, these fibers end in synapses with the postganglionic neurones, whose cell bodies are located there, and to which belong the postganglionic fibers that leave this ganglion through its various branches of distribution. Those branches which run to the internal carotid artery, known collectively as the internal. carotid nerve and forming the internal carotid plexus, carry postganglionic fibers which are distributed to the eyeball, lacrimal gland, mucous membrane of the nose, mouth, and pharynx and many of the blood-vessels of the head. The fibers to the salivary glands run by way of the branch to the external carotid artery

1 Contribution No. 54, February 15, 1918. 


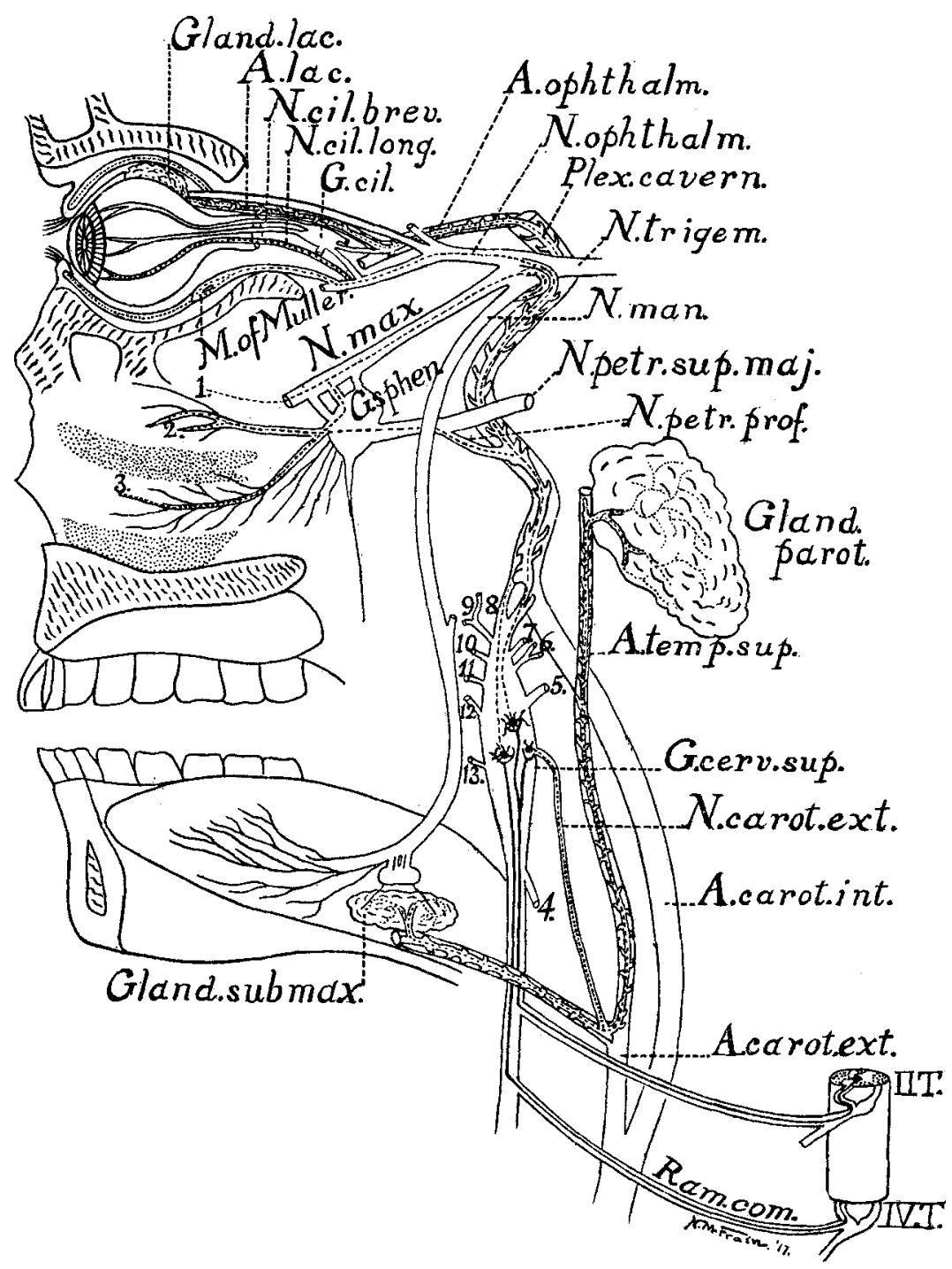

Fig. 1 Diagram representing the arrangement of the more important thoracicolumbar autonomic pathways to the head in man. The preganglionic fibers are indicated by solid lines. The cells of the postganglionic neurones are located in the superior cervical ganglion and their fibers are indicated by dotted lines. 1, Postganglionic fibers to sweat glands of the face; 2 and 3 , to the mucous membrane of the nose; $4, \mathrm{~N}$. cardiacus superior; $5, \mathrm{Rr}$. laryngopharyngei; 6 , branch to the $N$. hypoglossus ; 7 , branch to the N. vagus; 8 , n. caroticus internus; 9 , branch to the $\mathrm{N}$. glossopharyngeus; $10,11,12,13$, Rami communicantes (gray) to Nn. cervicales I, II, III, and IV. 
and follow along its branches to the glands. Through the superior cardiac nerve postganglionic fibers run to the heart in man. Other postganglionic fibers join the upper four spinal nerves and the ninth, tenth, and twelfth cranial nerves to be distributed to the blood-vessels and glands in the regions supplied by these nerves, and still others run by the laryngopharyngeal branches of the superior cervical ganglion to the larynx and pharynx.

This will serve as a general survey of the field to be studied. In the pages which follow we will take up in detail the structure of the superior cervical ganglion, sympathetic trunk and internal carotid nerve and pay particular attention to the synapses which occur in the ganglion.

\section{MATERIAL AND METHODS}

The superior cervical ganglion of man, the dog, and cat were prepared by the pyridine silver method and cut into sections 12 to 20 micra thick. Osmic acid preparations were also made from the dog and cat. Many of the preparations were cut into serial sections at right angles to the long axis of the ganglion, beginning at the internal carotid nerve and extending through the ganglion and some distance along the sympathetic trunk. Other ganglia were also examined, such as the stellate ganglion of the cat and the superior cervical ganglion in the rabbit.

In addition to the study of these parts in normal animals, experiments were carried out to determine the effect of partial and of complete degeneration of the preganglionic fibers. It had been noticed in a study of degenerating and regenerating nerves, made several years previously that certain fibers in the early stages of degeneration showed an increased affinity for silver. It was hoped that this might furnish a clue which would lead to the development of a differential stain for degenerating axons. A number of ganglia were prepared by the pyridine silver method sixteen or seventeen hours after section of the sympathetic trunk in the neck to see if by this method the preganglionic fibers might be made to stain more intensely through an increased affinity for the silver. So far we are not convinced 
that any advantage was obtained by this procedure. It is true that the majority of our best preparations of the preganglionic f.bers were obtained in this way, but since we occasionally obtained just as good stains in normal animals we are in doubt as to the value of the preliminary division of the fibers. We shall consider these as preparations of the normal ganglia since if there is any change it is only in the direction of an increased affinity of these fibers for the silver.

In order to obtain complete degeneration of the preganglionic fibers the sympathetic trunk was divided in the neck. The cperation was performed aseptically on cats and dogs, the nerve being cut about 2 inches below the ganglion. After periods of from eight to fifty days some of the animals were killed. It was fcund that after the longer periods some regeneration had occurred and the shorter periods were scarcely adequate for full degeneration. In order to avoid these difficulties, a second operation was performed on some of the animals twenty to fifty days after the first, the nerve being cut cephalad to the neuroma. Eight days after the second operation the animals were killed.

In dealing with small nerves and ganglia we have found that the pyridine silver stain often fails to give good results apparently because the volume of the tissue is too small. In order to overcome this difficulty we find it desirable to imbed the small nerve or ganglion in the spinal cord. For this purpose we have tied a fine silk thread to the sympathetic trunk and with a long fine needle have drawn the trunk with the attached superior cervical ganglion and internal carotid nerve into a lateral half of the spinal cord along the line of the ventral gray column. After fixation for two hours in ammoniated alcohol the block of spinal cord can be pared down with a razor until it forms a bar the crosssection of which is not more than $4 \mathrm{~mm}$. square. Within this block of cord the nerve is held extended and straight and is protected from the two direct action of the reagents. The cord is dissected away from the nerve just before it is dehydrated and cleared in preparation for imbedding. 
STRUCTURE OF THE CEPHALIC END OF THE SYMPATHETIC TRUNK

As has been said, the cervical portion of the sympathetic trunk serves to convey preganglionic fibers from the upper white rami to the superior cervical ganglion. Whether it also contains other than preganglionic fibers is a question which we will consider in this paper. In the cat this nerve, a short distance below the superior cervical ganglion, has the structure shown in figure 2. In cross-section it is uniform throughout except for one or two small well-defined bundles at the periphery. These bundles are not constant and, as we shall see, represent fine branches of distribution from the ganglion which have been incorporated for a short distance in the trunk.

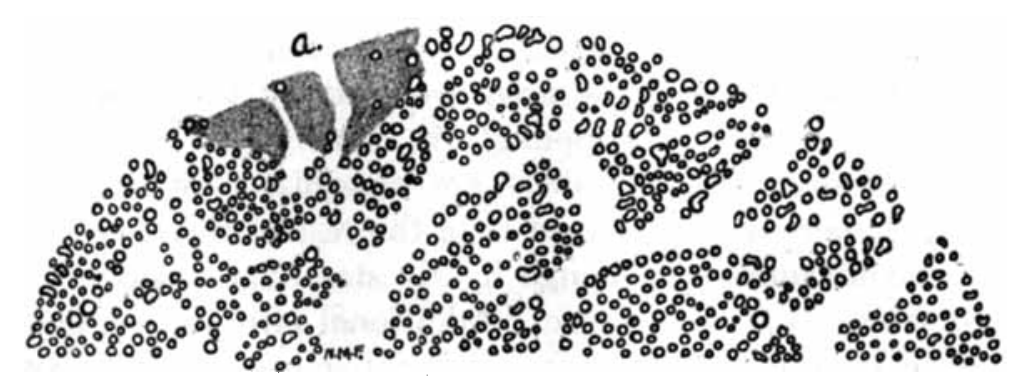

Fig. 2 From a section of the truncus sympathicus a short distance below the ganglion cervicale superius in the cat. a, area occupied by a bundle of unmyelinated fibers. Osmic acid. $\times 425$.

Exclusive of these peripheral bundles which really do not belong to it, the sympathetic trunk below the superior cervical ganglion in the cat consists almost exclusively of myelinated fibers as shown in figure 2 . These are uniformly distributed and closely packed. It is as well myelinated a nerve as there is anywhere in the body. The fibers are all rather fine. The majority vary in diameter from $1.5 \mu$ to $3.5 \mu$. Between these two extremes there are fibers of all sizes and about as many of one size as another. Fibers larger than $4.5 \mu$ are few in number but there may be two or three as large as 6.5 or $7 \mu$. Pyridine silver preparations show rather small axons, each surrounded by an unstained halo representing a myelin sheath; these are uniformly distributed, each well separated from its neighbor. There are 
no bundles of closely packed unmyelinated axons and no individual ones can be made out with certainty. From a study of the normal truncus sympathicus we may conclude that it is composed almost exclusively of small myelinated fibers.

The fine peripheral bundles, which represent branches of distribution from the superior cervical ganglion, can usually be followed in serial sections to the point where they are given off as fine branches from the trunk. They do not degenerate after section of the nerve more caudally. The structure of these peripheral bundles is entirely different from that of the rest of the nerve and corresponds to that of the other branches of distribution given off from the superior cervical ganglion. They contain a few small myelinated fibers, $1.5 \mu$ to $6 \mu$ in diameter, scattered among the unmyelinated fibers. Such a bundle is seen at $a$ in figure 2 where the area occupied by the umyelinated fibers is indicated by stippling. In osmic acid preparations bundles of unmyelinated fibers are recognized by their being somewhat more darkly stained than the rest of the background. A fascicle of axons, even though lightly stained, is easily differentiated from connective tissue. Additional information may be obtained by the study of the degenerated nerve. In an osmic acid preparation taken from a cat eight days after neurotomy of the sympathetic trunk in the neck most of the medullated fibers are degenerated, although a few cannot be distinguished from normal fibers. But eighteen days after the operation all the medullated fibers were degenerated except for a small number in a single peripheral fascicle, such as has been described and which is not to be regarded as belonging to the nerve. There were 16 myelinated fibers in this bundle varying in size from $1.8 \mu$ to $3.6 \mu$. All the other myelinated fibers in the nerve were degenerated. From this we may conclude that all the myelinated fibers in the cephalic end of the sympathetic trunk (exclusive of branches of the superior cervical ganglion which may be incorporated with it for a short distance) are ascending fibers. There are no medullated fibers arising in the superior cervical ganglion and running to the ganglia placed more caudally in the truncus sympathicus. 
Waller and Budge showed long ago that the sympathetic trunk after section in the neck degenerated toward the superior cervical ganglion. Their results have been confirmed by Langley ('96, '00). This author used the rather unsatisfactory method of examining the degenerated nerve in teased preparations stained with osmic acid. He found, however, just as we, in sections stained with osmic acid, that some fine branches of the superior cervical ganglion may accompany the nerve for a certain distance. He also found that occasionally a branch from the vagus might run to the superior cervical ganglion and accompany the nerve for a way. This may have been the depressor nerve (p. 374).

After the sympathetic trunk below the stellate ganglion and the rami communicantes to the first and second thoracic nerves were cut and time allowed for degeneration, he found no sound myelinated fibers in the cervical portion of the nerve, aside from the bundles just mentioned which may happen to be included in the same sheath with it. He concluded that no myelinated fibers run from ganglion to ganglion through this nerve and none join it from the cervical rami communicantes.

We have pyridine silver preparations of the degenerated nerve in both cat and dog. In each case the structure is the same. Take, for example, Cat XII which was killed fifteen days after the division of the sympathetic trunk in the neck. In that part of the nerve just below the superior cervical ganglion the sections stained with silver showed two fascicles of fine undegenerated axons mostly unmyelinated at the periphery of the trunk. Following the sections caudally through the series, one of these fascicles can be seen to leave the trunk, but the other remains with it as far as our series goes, although it would no doubt separate off a little farther down.

Aside from these two peripheral fascicles, which, properly speaking, do not belong to the nerve, almost all of the axons have degenerated. Here and there throughout the section there seems to be an isolated unmyelinated axon of normal appearance. These normal unmyelinated fibers are not numerous. In fact, since we have never seen such isolated unmyelinated axons 
elsewhere except in regenerating nerves, we are somewhat skeptical of this observation. The presence of these few axons descending from the superior cervical ganglion, however, raised the questions, are there commissural fibers joining the superior cervical with the stellate or other ganglia?

Here we can take up only the question of the existence of fibers connecting cells in different ganglia, and will leave out of account for the moment that of the interconnection of the cells within a single ganglion. According to Langley, there is no evidence which would justify us in assuming the existence of commissural fibers between the cells of different ganglia, and in certain parts of the sympathetic nervous system he has given strong evidence that no such connections exist. The mass of evidence which he has presented is very convincing, but is too extensive to be summarized here. The reader is referred to the account in Schäffer's Physiology, vol. 2, p. 683, and other articles by Langley in the Journal of Physiology, vol. 25, p. 468, and vol. 31, p. 244. We can refer here only to that part of the evidence which concerns the cervical portion of the sympathetic trunk. After this nerve was cut below the ganglion stellatum, and the rami communicantes to the first and second thoracic nerves divided and time allowed for degeneration, stimulation of the trunk in the neck produced no effect on the pupil, nictitating membrane, eyelids, hairs, or blood-vessels. Hence the cells of the ganglion stellatum or the middle cervical ganglion do not send nerve fibers to the superior cervical ganglion or to the head by way of this nerve. Even in the normal cat stimulation of this nerve produces no vasomotor, pilomotor, or secretory effect in the territory supplied with such fibers by the ganglion stellatum. It is clear, then, that the superior cervical ganglion does not send commissural fibers to the vasomoter, pilomoter, or secretory nerve cells of the ganglion stellatum which include the great majority of the cells in the ganglion. It is easy to show that stimulation of the sympathetic trunk in the neck is without appreciable effect on the heart of the cat. Hence no fibers descend from the superior cervical ganglion to the cardio-accelerator neurones of the middle cervical and stellate ganglia. 
Langley has shown that stimulation of the sympathetic trunk in the neck causes no general body reflexes of any kind. It must, therefore, be devoid of sensory fibers, at least of those carrying painful afferent impulses. We have been able to confirm this physiological observation and our histological results are also in agreement with it. On page 432 we will show that the characteristic sensory fibers of the sympathetic trunk are the large myelinated and the unmyelinated. Except for two or three large myelinated fibers, there are no fibers which would be interpreted as sensory ascending in the cervical portion of the sympathetic trunk.

\section{STRUCTURE OF THE NERVUS CAROTICUS INTERNUS}

The chief set of branches given off by the superior cervical ganglion ascends from its upper pole to the internal carotid artery. Of these one or two are of large size in the cat. These large ones are easily and positively recognized in serial sections of the ganglion and its branches. The entire group of from three to five branches forms the nervus caroticus internus. It consists of both myelinated and unmyelinated fibers the latter of course predominating. Figure 3 shows the relative size, number, and arrangement of the myelinated fibers in this nerve in the cat. These fibers are rather widely separated by great numbers of unmyelinated axons and are of about the same size as those of the sympathetic trunk. They vary in diameter from $1.5 \mu$ to $4.5 \mu$ with an occasional larger fiber up to $7 \mu$. Their distribution is quite uniform throughout the nerve. The thickness of their myelin sheath seems to be somewhat less than that of those in the sympathetic trunk.

These myelinated fibers are so numerous that interest is at once aroused as to their source, and the possibility suggests itself that they are preganglionic or perhaps afferent fibers from the trunk which have run through the ganglion without interruption. This possibility is easily excluded, however, by section of the trunk below the ganglion. After all the myelinated fibers in that trunk have degenerated the structure of the internal

THE JOURNAL OF COMPARATIVE NEUROLOGY, voL. 29, No. 4 
carotid nerve remains unchanged and contains as many myelinated fibers as the nerve of the opposite side. Measurements show that fibers of all sizes from 1.5 to $7 \mu$ are present, showing that there has not occurred a dropping out of the fibers of a particular size. In fact, figure 3 represents an internal carotid nerve after the complete degeneration of the sympathetic trunk below the superior cervical ganglion of the same side, but illustrates perfectly well the normal structure of the nerve.

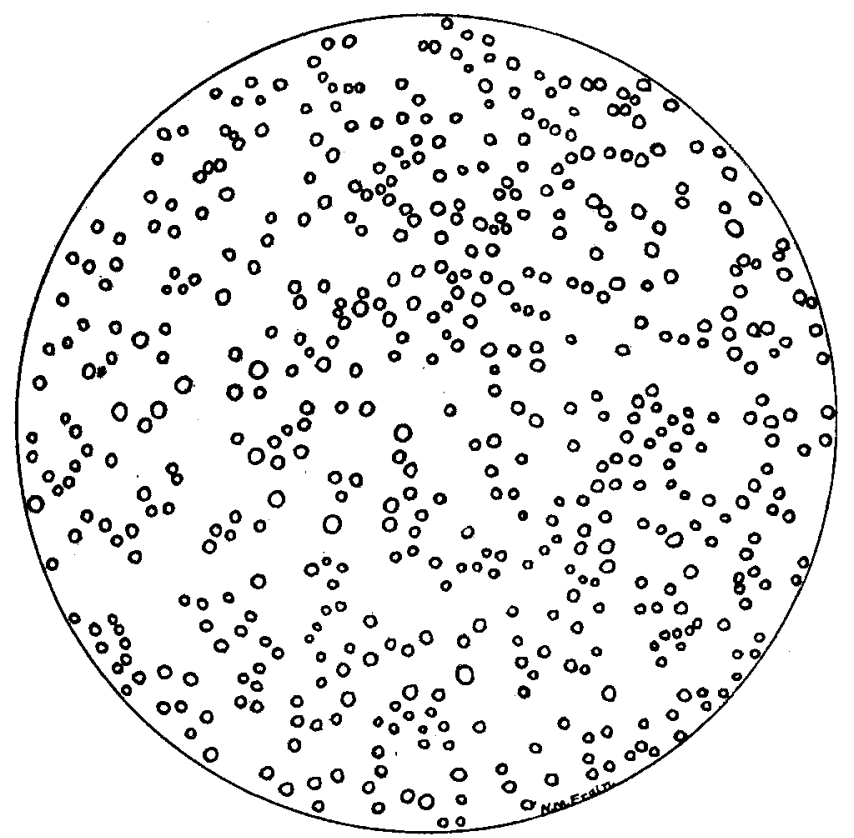

Fig. 3 From a section of the nervus caroticus internus in the cat. Osmic acid. $\times 1425$.

One must also consider the possibility of these myelinated fibers being contributed through the rami connecting the superior cervical ganglion with the upper cervical and certain of the cranial nerves. Against this assumption are the observations that can be made on serial sections through the superior cervical ganglion and the internal carotid nerve after degeneration of the trunk. 
The myelinated fibers in such a ganglion are extremely few at the caudal pole, but increase gradually toward the cephalic end of the ganglion. They are scattered uniformly through the cross-section of the ganglion, until they begin to assemble at the upper pole to enter the internal carotid nerve. The few myelinated fibers that can be seen in the various side branches of the ganglion (to the cervical and cranial nerves) are at once lost in the ganglion. There are no bundles of medullated fibers running through the ganglion from one branch to the other. We believe that all or at least most of the myelinated fibers in the branches of the superior cervical ganglion arise from cells located in that ganglion. This will receive additional support from more detailed study of the structure of the superior cervical ganglion to follow.

Langley ('96) has shown that after section of the branches peripherally of the superior cervical ganglion nearly all of the myelinated fibers which remain connected with the ganglion are normal, while nearly all of those separated from the ganglion have degenerated, showing that the cells of origin of the great majority of these fibers are located in that ganglion. These observations were made on the cat. In the dog he has traced two small bundles of fibers from the tympanic plexus by way of the internal carotid artery to the superior cervical ganglion.

It is therefore evident that a considerable number of the axons arising in the superior cervical ganglion acquire a myelin sheath. This is in keeping with the results of v. Kölliker ('94), Dogiel ('95), Langley ('96), Michailow ('11), and others. It is interesting to note, however, that Cajal ('11) is of the opinion that the axons of the cells of the sympathetic ganglia never acquire myelin sheaths. It is easy to understand how he may never have been able to trace such an axon into a myelinated fiber, but as we have seen this is not the only line of evidence that can be brought to bear on the problem. All things taken into consideration, the evidence is conclusive that postganglionic axons not uncommonly acquire myelin sheaths. 


\section{STRUCTURE OF THE SUPERIOR CERVICAL GANGLION}

While we have examined a number of ganglia, including the stellate and coeliac, the observations which we have to report are restricted to the superior cervical ganglion. In the account which follows we will consider the results obtained by others, topic by topic, as we present our own. Unless otherwise stated, citations from the literature are applicable to the collateral ganglia and to all the ganglia of the sympathetic trunk. They should not be carried over without qualification to the terminal ganglia. These present special problems and require separate consideration.

Ganglion cells. It is well known that almost all of the neurones in the sympathetic ganglia are multipolar, although there are also a restricted number of unipolar and bipolar cells located near the poles of a ganglion or within its longitudinal fiber bundles, Huber ('99). Like other nerve cells these neurones have but a single nucleus, except in rodents. In the rabbit we have seen many cells with two nuclei. These have been figured and described with a summary of the related literature by Huber ('99). The neurofibrils of the cells of the sympathetic ganglia have been described by a number of authors, including Michailow ('08) and Cajal ('11). The Nissl granules have been described and figured by Carpenter and Conel ('14).

Dendrites. The dendrites of the cells of the sympathetic ganglion may be divided into two chief categories-intracapsular and extracapsular. The former, although presenting great variety in length and form, are all situated beneath the cell capsule. Although these intracapsular dendrites are common in the sympathetic ganglia of man, they are rarely met with in the other mammals. Michailow ('11), in his careful study of the collateral and trunk ganglia in horses, dogs, cats, rabbits and guinea-pigs, described and figures only one form of subcapsular dendrite. These are present on his cells of types II and V. They are short and club-shaped (fig. 8, a). There are usually from five to seven of them and they begin as relatively thick fibers soon going over into bulbous endings. A fiber may divide and end in two such clubs. The expanded ends of these 
dendrites usually contain pigment in large quantities and are sometimes vacuolated. Cajal ('11) does not describe any subcapsular dendrites in the sympathetic ganglia of animals, although they are very prominent in his descriptions and figures of these ganglia in man. But these dendrites were demonstrated in the human ganglia by means of his silver stain which was not used in his earlier studies on animals.

It might be supposed that the use of the newer silver stains would demonstrate their general occurrence in the mammalian sympathetic ganglia, but in pyridine silver preparations of the superior cervical ganglia of cats and dogs we have seen no cells with subcapsular dendrites. This shows that they must be relatively rare here and establishes a very striking contrast between the superior cervical ganglion of man and that of the carnivora.

The intracapsular dendrites reach their highest development in man. Here they give rise to complicated subscapsular formations which were first described by Cajal ('11), whose observations have been confirmed by Marinesco ('06). Both investigators worked with the superior cervical ganglion stained by the Cajal method. Their observations are confirmed by our own observations on the human superior cervical ganglion stained by the pyridine silver method. The account which follows is based on our own preparations, but is in accord with the results of the two investigators who preceded us. The subcapsular dendrites are arranged in a great variety of ways underneath the capsule of the cell from which they take origin. In general they may be said to give rise to two types of complicated intracapsular networks which Cajal has called dendritic crowns and glomeruli.

Figure 4 furnishes a good example of a dendritic crown. Numerous dendrites of varying caliber come off from the cell and run toward the inner surface of the capsule where, with or without branching, they turn to run in the subcapsular space. Here they cross and recross, but do not anastamose, and form an open network more or less uniformly distributed around the cell. In some cases these dendrites can be seen to end in small bulbs 


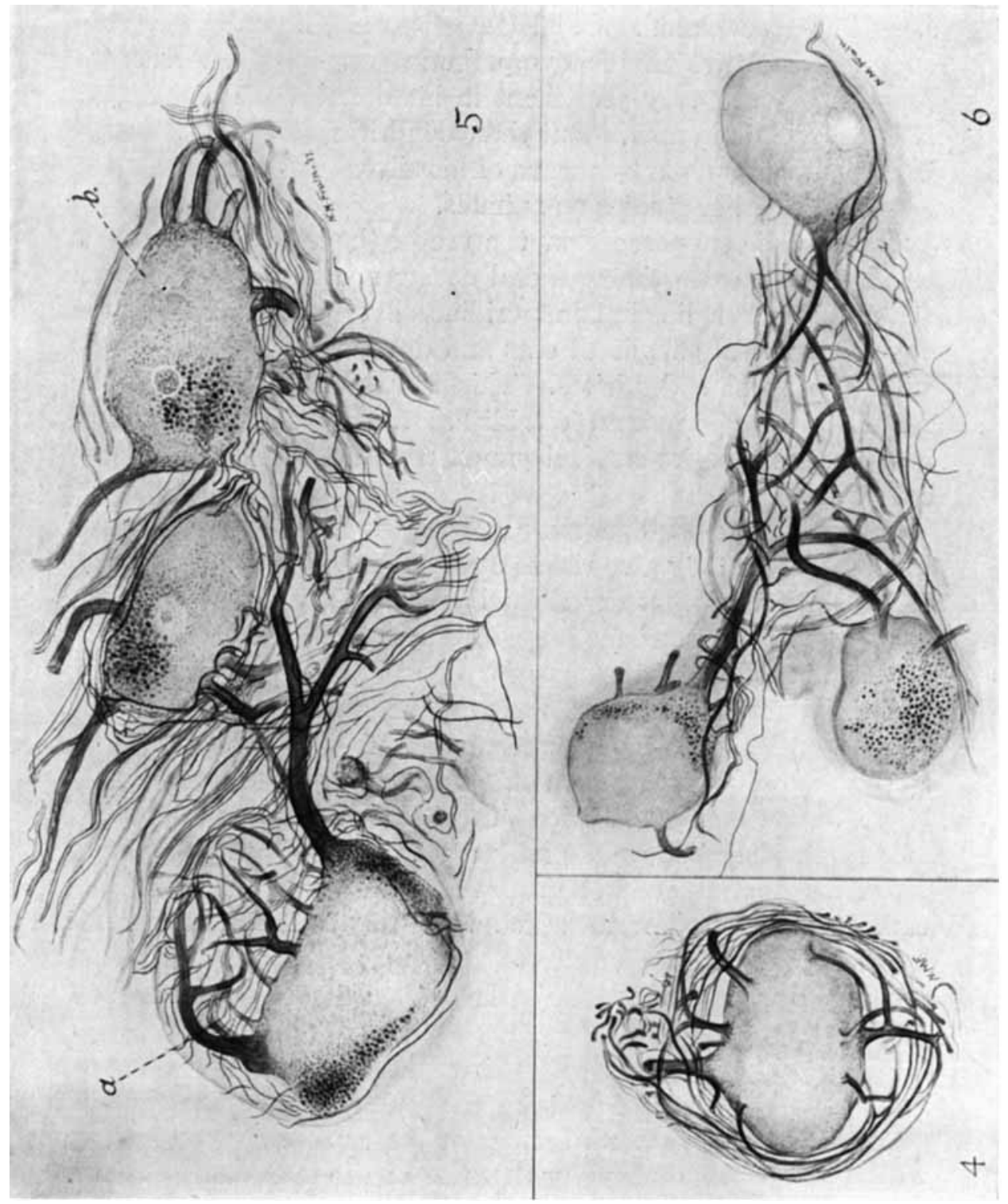


or rings. The long thick process which is seen piercing the capsule in the illustration is probably the axon, although it might be an extracapsular dendrite. In that case one would have to assume that the axon came off from that surface of the cell which has been cut away at the plane of section.

According to Cajal, these dendrites frequently apply themselves against the capsule to terminate on its internal surface or among the satellite cells by pear-shaped thickenings. Sometimes they are more delicate and bend in beneath the capsule to terminate by fine pale extremities. Sometimes they run beneath the capsule in great circles about the cell. The dendritic nest which envelops the cell is easy to distinguish from the ramifications of axons by the greater caliber of its fibers and the rarity of its divisions. Cajal's figures show that the spaces among the subcapsular dendrites contain small cells which he calls satellite cells.

The dendrites which enter into the formation of the glomeruli are also subcapsular, but are usually coarser than those just described. Instead of coming off from all parts of the surface of the cell, they usually arise from a restricted region. Branching repeatedly and interlacing they form a mass of considerable size over which the capsule of the cell is continued. Cajal has shown that the spaces between the dendritic branches are occupied by satellite cells. Following his classification, we may enumerate simple, bicellular, tricellular, and multicellular glomeruli according to the number of neurones the dendrites of which enter into their formation.

The simple glomeruli are formed from the dendrites of one cell. They are short and thick, come off from one side of the cell, and raise the capsule to form a pocket within which these dendrites

Fig. 4 Nerve cell surrounded by dendritic crown from the ganglion cervicale superius of man. Pyridine silver. $\times 800$.

Fig. 5 From the ganglion cervicale superius of man. a, unicellular dendritic glomerulus; $b$, cell provided only with extracapsular dendrites. Pyridine silver. $\times 800$.

Fig. 6 Tricellular glomerulus from the ganglion cervicale superius of man. Pyridine silver. $\times 700$. 
branch and intertwine (fig. 5, a). All transition stages are found between the simple glomeruli and the dendritic crowns. When the glomerulus is located on the side from which the axon arises it may be prolonged out for a short distance along the axon, giving rise to a comet-shaped formation.

The glomeruli formed from the dendrites of more than one cell may be called composite glomeruli and are somewhat more complicated than the simple glomeruli just described. The large subcapsular dendrites of two or more cells converge toward each other to form a circumscribed mass of branching and interlacing dendrites. Figure 6 gives a good idea of a tricellular glomerulus, which, along with the three cells, seems to be enclosed in a single capsule. The capsules and subcapsular satellite cells are not well differentiated in pyridine silver preparations, but, according to Cajal, the glomeruli are surrounded by a capsule that separates them from the fiber bundles. The capsule is better defined in the bi- and tricellular than in the multicellular forms.

The fine black fibers seen interlacing with the dendrites in figures 5 and 6 are the branches of axons and will be discussed in another place.

The extracapsular dendrites pierce the capsule and run for longer or shorter distances among the cells, helping to form an intercellular plexus of dendritic and axonic ramifications. The cells of the superior cervical ganglion of the dog and cat are provided almost exclusively with this type of dendrite. Such dendrites are also numerous in this ganglion in man. Here they may come from cells devoid of subcapsular processes (fig. 5, $b$ ) or from cells provided with dendritic crowns or glomeruli (fig. 5, a). They are usually coarse fibers and may branch near the cell or may remain unbranched until they leave the section. Often it is possible to trace them much longer distances than is indicated in the figure, but in no case could they be followed to what seemed to be their true termination (fig. 7). Cajal differentiates three types of cells in the human superior cervical ganglion: 1) cells provided exclusively or almost exclusively with subcapsular dendrites; 2) cells provided only with long dendrites, and 3) 
cells provided with both kinds of dendrites. While such a classification facilitates description it must not be supposed that these types are separated by sharp lines of cleavage or that there is any reason to assign them different functions.

In pyridine silver preparations of the superior cervical ganglion of dogs and cats the dendrites have not been very well stained. We could find only extracapsular dendrites, but could trace none of them to their termination. Figure 12 gives an idea of how they look when freed from intercellular axonic ramifications. In order to make an intelligent analysis of the functional con-

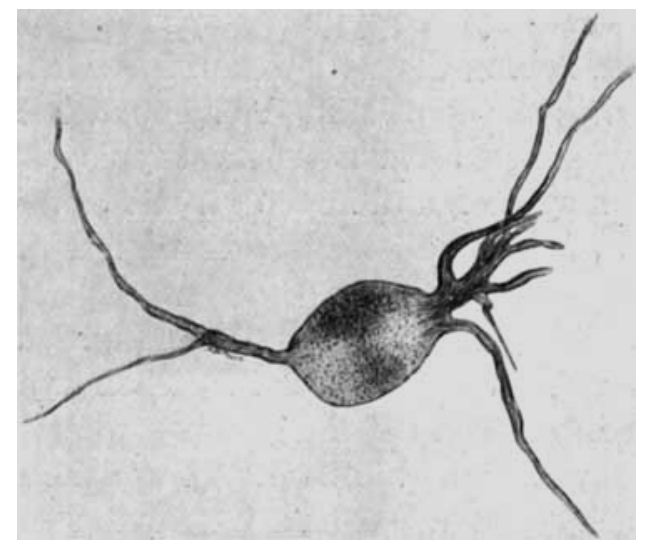

Fig. 7 Cell with long extracapsular dendrites from the human superior cervical ganglion. Pyridine silver. $\times 400$.

nections in the ganglia it is necessary to have a clear idea of the course and termination of these extracapsular dendrites.

Concerning the true endings of these dendrites our preparations, which could not be made very thick, give us no information because all the long dendrites seem to be cut off at the surface of the section. According to Cajal ('11), there are three ways in which these long intracapsular dendrites in the human superior cervical ganglion end: 1) They may run into a fascicle of dendritic fibers where they run parallel to the other fibers of the fascicle and within which they may end with long interstitial appendages. At other times they end in olive-shaped extremities, or in fusiform swellings which give rise to fine varicose branches. 
2) They may end in glomeruli where they encounter the branches of other dendrites of the same kind. As indicated in his figures, such glomeruli are located at a distance from the cells of origin of the dendrites concerned. 3) They may end in pericellular baskets. These dendritic baskets have been found in animals by Cajal ('11), Van Gehuchten ('90), Sala ('92), and Michailow ('11), and will be discussed more in detail in connection with the account given by the latter author.

Michailow ('11) has enumerated nine types of cells in the sympathetic ganglia of mammals. This grouping like that of other authors is chiefly of value as an aid to description, since there is no evidence that any one type is responsible for a particular function. From among the various forms, which, according to him, the dendrites of the cells in the sympathetic ganglia may assume, we have selected five as the most typical and significant. Such dendrites may be found in the ganglia of the sympathetic trunk as well as in the collateral and terminal ganglia. They are represented in figure 8 .

1. Dendrites ending in a brush formation (fig. $8, a$ ). These are given off in small numbers (1 to 4) from Michailow's Type II cells. They run between the cells of the ganglion where some of them end; others enter bundles of fibers that leave the ganglion. He has followed such a dendrite from a ganglion of the solar plexus of the horse and seen it run as a typical unmyelinated fiber into another ganglion of the same plexus. These dendrites end in special formations in the shape of little brooms, consisting of numerous end branches beset with enlargements. These thickenings are of various shapes and sizes. Usually they are flattened and have the appearance of end plates or of large varicosities.

2. Dendrites terminating in end plates (fig. $8, b$ ). These are given off from Michailow's Type III cells. They begin as rather thick processes which in unipolar and bipolar cells may be so thick that it is hard to tell where the cell body ends and the dendrite begins. Sometimes these dendrites end in the same ganglion, sometimes they join bundles of nerve fibers and either end in them or run with them to end in other ganglia. Some remain thick and coarse to their end, others branch and become 


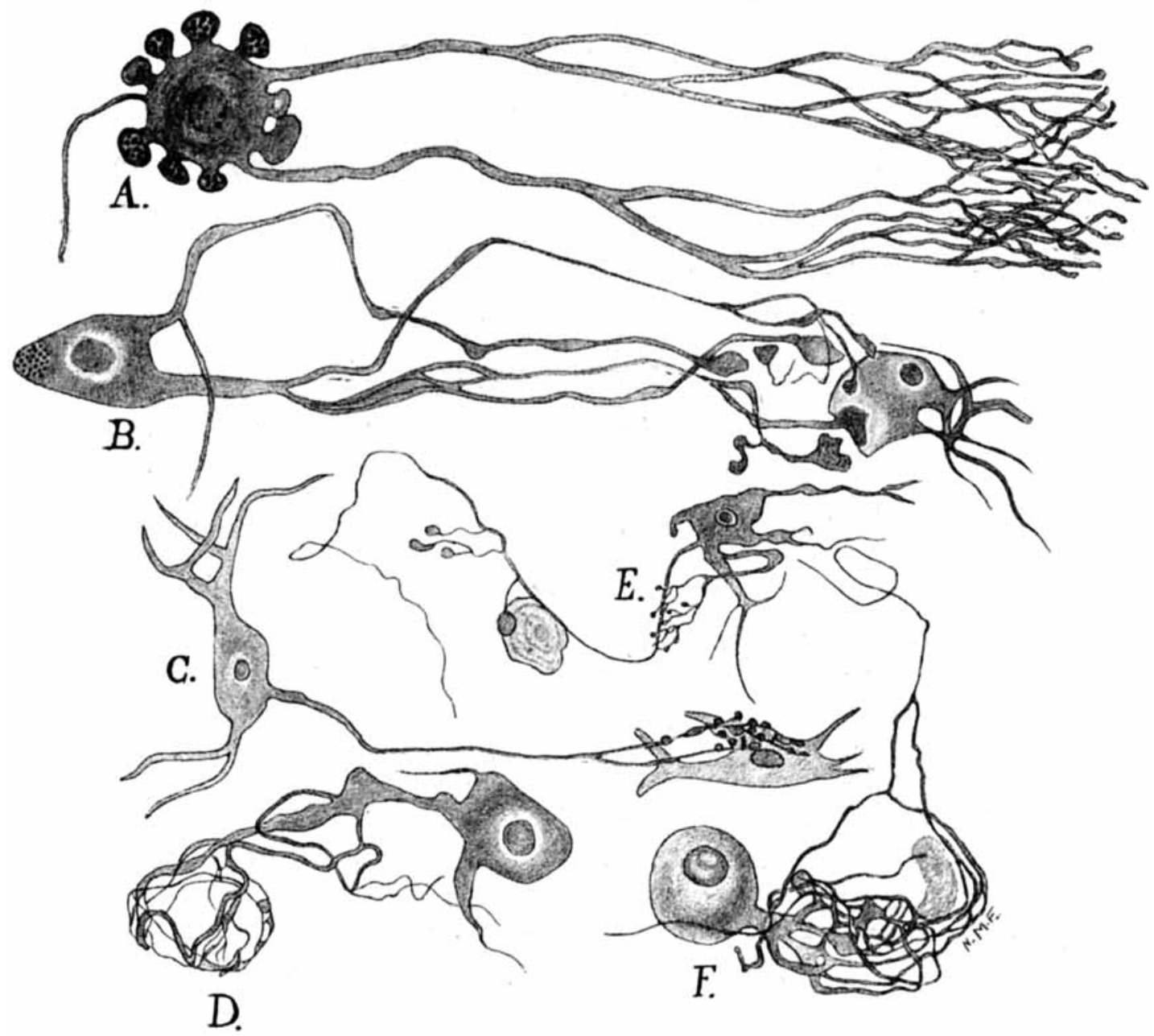

Fig. 8 Sympathetic ganglion cells showing various types of dendrites. Redrawn from Michailow ('11). All were stained with methylene blue; $a$, cell of Michailow's Type II from the ganglion mesentericus superius of the horse; $b$, cell of Type III from the ganglion coeliacum of the horse; $c$, cell of Type IV from the ganglion stcllatum of the horse; $d$, cell of Type VI from the ganglion cervicale superius of the dog; $e$, cell of Type IX from the ganglion coeliacum of the horse; $f$, cell of Type VIII from the ganglion cervicale superius of the dog. 
thin, take on the character of unmyelinated fibers and run out of the ganglion. The endings are in the form of plates of various sizes and shapes. These may lie free in the connective tissue or may be pressed against the outside of the capsules of other cells so close as to produce an impression on the cells. Other end plates of this type are found in the fiber bundles outside the ganglia. He found great numbers of such end plates in the fiber bundles of the solar plexus.

3. Dendrites ending in a number of fine branches with end bulbs closely grouped together as illustrated in figure $8, c$. Such dendrites arise from Michailow's cells of Type IV. They branch freely and occupy much space, greatly increasing the territory of these neurones. They may end in the same or in other ganglia. Near their termination they begin to divide di- and tricotomously. The branches are provided with terminal enlargements which may be rounded or pear-shaped. All the branches of a dendrite form together an end-apparatus, which may vary in size and appearance, but is always applied to the outer surface of the capsule of a cell of Type IV. That is to say, these fibers arise from cells of Type IV and end upon the surface of the capsules of other cells of Type IV.

4. Dendrites forming pericellular nests (fig. 8, $d$ ). These arise from the cells of Michailow's Type VI, are usually short, and divide repeatedly. The branches approach another cell, and anastamosing with each other form a network that encloses the cell. Sometimes such a basket-like network surrounds the cell from which the dendrite arose. Similar formations have been described by Dogiel, according to whom they are always extracapsular. As already mentioned, Cajal, Van Gehuchten, and Sala have seen such dendritic nests. The significance of these structures can best be discussed in a later paragraph.

5. Dendrites the branches of which anastomose to form a true net out of which a fine fiber, probably the axon, arises (fig. $8, f$ ). One or more dendrites break up into a great number of fine branches which anastomose with each other, giving rise to a network. Out of the net fine filaments arise, which join together to form a smooth fiber that remains unaltered as far as it 
can be followed. Michailow thinks it probable that these smooth fibers are axons. It will be seen that these neurones resemble some described by Dogiel in the spinal ganglion.

Are there special sensory dendrites in the sympathetic ganglia? This problem has been in the foreground ever since 1896 when Dogiel published his paper on "Zwei Arten sympathischer Nervenzellen." The one type of dendrite which he thought belonged to motor cells branched repeatedly in the neighborhood of the cell and ended within the ganglion; the other, which he thought belonged to sensory cells, resembled unmyelinated nerve fibers and could be traced long distances. Many of them could be followed out of the ganglion and were thought to end as sensory fibers in the viscera. Cajal ('11) finds no evidence in favor of the sensory function of these long dendrites and was not able to find any of them leaving the ganglia and associated nerve trunks to end in the viscera.

Carpenter and Conel ('14), working with Cajal's method on the superior cervical ganglion of the cat, could find cells answering to the description of Dogiel's two types, but were not convinced that such cells represent two distinct categories, since all gradations between the two extremes were found. In Nissl preparations all the cells of the sympathetic ganglia appeared to Carpenter and Conel to be of one type. In the cerebrospinal system it is easy to recognize sensory and motor cells by the arrangement of their chromatophile substance, but all the sympathetic ganglion cells seemed to have a structure intermediate in character between that of the cerebrospinal sensory and motor types. Since these results would indicate that there is but one functional type of cell in these ganglia and since we know that the majority of the cells are motor, the probability against the presence of sensory cells is increased.

So far as we have been able to find no one has confirmed Dogiel's account of the sensory type of cell except Kuntz ('13), who found certain structures which could be interpreted in this way. Nor has the correlated observation of Dogiel, that fibers, arising from sensory cells in the sympathetic ganglia, run to end in pericellular baskets about spinal ganglion cells, been much better 
supported. In regard to this point Huber ('13) has recently said

the evidence presented by Cajal, Dogiel, Retzius, Huber, and others cannot be regarded as entirely conclusive, since it has not been determined that the fine medullated fibers or the unmedullated fibers which appear to enter the spinal ganglia from without and end in pericellular plexuses, are, in fact, the neuraxes of sympathetic neurones.

Very strong evidence has been presented by Langley ('03) to show that no medullated sensory fibers run from the sympathetic to the spinal ganglia.

As regards the white rami, which contain most of the afferent visceral fibers, there is conclusive evidence that the very great majority of them have their trophic center in the posterior root ganglia. It consists in the fact that after intraspinal section of a nerve just peripherally of the posterior root ganglia, cither all, or all but a few, of the medullated fibers in the white rami degenerate; and that after section of the sympathetic or of the splanchnic or of the inferior splanchnics no degenerated fibers are present in the white rami.

Similarly in the sacral autonomic system, the pelvic nerves contain about 1,000 afferent nerve fibers, and about twice this number of efferent nerve fibers; on cutting the roots of the sacral nerve, as shown by Anderson and myself, about half a dozen fibers only remain undegenerated in the pelvic nerve, and these are probably post-ganglionic medullated fibers.

Axons of the cells of the sympathetic ganglia. In pyridine silver preparations of the superior cervical ganglia of the cat, $\mathrm{dog}$, and man, it is very difficult to follow an axon for any considerable distance. In fact, it is usually no easy matter to tell which of the several processes of a cell is to be regarded as an axon. In a preceding section of this paper it has been shown that some of these axons acquire a myelin sheath. According to Kölliker ('96) and Langley ('00), these axons always end at the periphery, and never terminate in the sympathetic ganglia.

According to Cajal ('11), who worked with the Golgi and methylene blue stains on the sympathetic ganglia of animals and with his silver stain on the superior cervical ganglion of man, the axons of the cells of the sympathetic ganglia are rather thick, smooth, and devoid of branches. He says that his anatomical studies are in accord with the physiological experiments of Lang- 
ley and indicate that the axons of these cells dispose themselves in one of the three following ways: 1) Usually they run transversely to the long axis of the ganglion to enter a gray ramus. In the initial part of their course these fibers do not give rise to branches. 2) The axons may run through a connecting nerve trunk into another ganglion. $\mathrm{He}$ is not able to say whether these axons only run through the second ganglion or whether they make connections with its cells. In the chick embryo he at one time described collaterals coming from those longitudinal fibers of the ganglia which take origin in neighboring ganglia. He is now inclined to doubt this observation and thinks it likely that these collaterals all come from fibers that have entered the sympathetic trunk through white rami at other levels. 3) In some cases they leave the ganglion and run toward the neighboring arteries in the visceral nerves.

Sala ('93) described two kinds of fibers in the sympathetic ganglia. Those of one variety are unbranched, varicose, and unite to form smaller or larger fascicles which run through the ganglion in every direction. These are the axons of the cells of the sympathetic ganglia. The fibers of the other kind are a little larger, non-varicose, and give off collaterals which are finer and in their turn ramify abundantly. These are less numerous than the first and are found almost exclusively in the branches from the cerebrospinal system. It is not improbable, he says, that these are of cerebrospinal origin.

In his elaborate description of nine types of cells in sympathetic ganglian Michailow has given very few details regarding the axons. However, it is to be noted that in none of these nine types does he describe the axon as terminating in a sympathetic ganglion and in only one does he describe it as giving off collaterals (fig. 8, e).

v. Lenhossék ('94), using Golgi preparations of the chick, traced axons of sympathetic ganglion cells into the neighboring ganglia, but did not say what became of them there. In one case he saw fibers entering a ganglion from a visceral nerve break up into branches. He considered these the axons of cells lying somewhere in the visceral ganglia. From what we know now they might just as well be interpreted as the endings of long dendrites. 
The axons of Dogiel's Type II cell are figured by that author as passing through several ganglia giving off collaterals and finally ending by branching in another ganglion. In the text, however, he does not claim to have followed such an axon to its termination. But, as we have said before, no one has been able to confirm Dogiel's findings in regard to these cells.

Both Dogiel ('95) and Huber ('99) are of the opinion that the fine fibers which enter the ganglion through its various branches and take part in the formation of the intercellular plexuses are the axons of cells in other sympathetic ganglia. Satisfactory evidence of this is not presented, however, and in the next section of this paper we will present what seems to be conclusive evidence that these fine fibers are of cerebrospinal origin.

While it has not been shown that the axons of sympathetic ganglion cells ever end in connection with the cells of the same or adjacent ganglia, it seems to be well established that these axons may give off collaterals within these ganglia. The axons have been seen to give off collaterals either in the same or adjacent ganglia by v. Lenhossék ('94), Dogiel ('95), and Michailow (11). These do not seem to be present on the majority of the axons. Michailow is the only one who has seen the mode of termination of these collaterals. According to him (fig. 8), they end in little plates, either in the connective tissue of the ganglion between the nerve cells or pressed against the capsule of a cell. From their mode of termination it is not evident how these collaterals could serve to transmit impulses from one neurone to another. They rather resemble certain collaterals on the axons of spinal ganglion cells, seen by Huber, Dogiel, and Ranson, which since many of them end on the cell from which the axon arose cannot serve for the spreading out of nerve impulses.

Huber ('13), in summing up the evidence concerning the interconnections of the cells of the sympathetic ganglia, concludes that "there is at hand morphologic evidence that the neuraxes of sympathetic neurones, the cell bodies of which are in one ganglion, terminate either on the cells of the same ganglion or of other ganglia." To us the evidence seems far from convincing. Such fragmentary and unsatisfactory histological evidence as 
may exist is more than off set by the strong physiological evidence against such connections. Some of this physiological evidence will be briefly presented in a succeeding paragraph.

The intercellular plexus. Throughout the ganglion there is a rich plexus of dendritic branches and fine axons. This has been described and figured by Dogiel ('95), Huber ('99), and Michailow

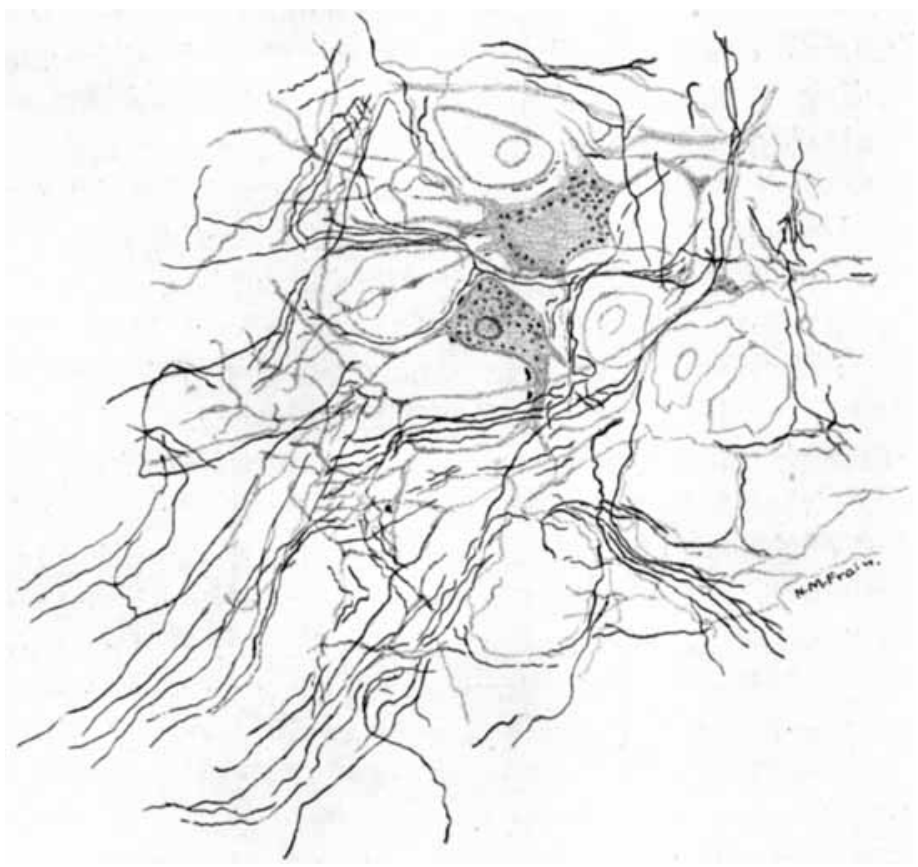

Fig. 9 Intercellular plexus formed by dendrites and myelinated and unmyelinated fibers from the semilunar ganglion of the cat. Redrawn from Huber ('99).

('11). The part which the dendrites take in this formation has been discussed in a preceding section. We are interested here chiefly in the axonic ramifications which help to constitute it. According to Huber, one of whose drawings is reproduced in figure 9, there are in addition to the medullated fibers entering the ganglion from the white rami, "small medullated fibers, which may be traced from this or that nerve root of a ganglion" into 
the ganglion where "they are found branching and rebranching, and forming, with the dendritic processes of the ganglion cells, what Dogiel has described as the intercellular plexus." Huber quotes with approval the conclusion of Dogiel ('95): "Die feinen Fasern, welche in den Ganglien mit intercellularem Geflechte endigen, zu den sympathischen, augenscheinlich vorzugsweise markhaltigen Fasern gehören." It is interesting to note that Huber was able to trace some of the fine unmyelinated fibers of this plexus to definite endings on neighboring dendrites.

According to Dogiel ('95), whose observations were made on the terminal ganglia, the finer myelinated and unmyelinated fibers enter the ganglion, branch and intertwine, and break up into fine branches which cross in various directions and finally break up into finer fibers of uncountable number. These form a thick plexus among the cells and at the periphery of the ganglion. The fibers of the plexus are in contact with the dendrites, but separated from the cell bodies by their capsules. All the fibers of the plexus are beset with varicosities.

Michailow's ('11) conception of the intercellular plexus differs from that of the two preceding authors i. that, according to him, the constituent fibers of the plexus anasiomose with each other forming a closed network. By means of th:s network all or at least many of these fibers are united together, one neurone being in this way united with many others. As will be seen later, there are good reasons for discarding this part of Michailow's description of the intercellular plexus.

In preparations of the superior cervical ganglion of the cat or dog by the pyridine silver method one can readily see a plexus of fine unmyelinated fibers running among the cells in every direction through the ganglion (fig. 10). The dendrites are not well stained in these preparations and only their coarser branches are visible. The finer dendritic ramifications, which, according to those who have worked with the methylene blue stain, help to form the intercellular plexuses, are not to be scen. In these preparations the network of fibers under discussion corresponds only to the axonic constituents of the intercellular plexuses of Dogicl and Huber. 
The constituent fibers of this plexus stain rather heavily with silver and range in color from light brown to black. They also vary greatly in size, the smallest being perhaps not more than one-eighth the thickness of the largest. The larger axons can often be seen to branch, but the smaller ones seem to run for

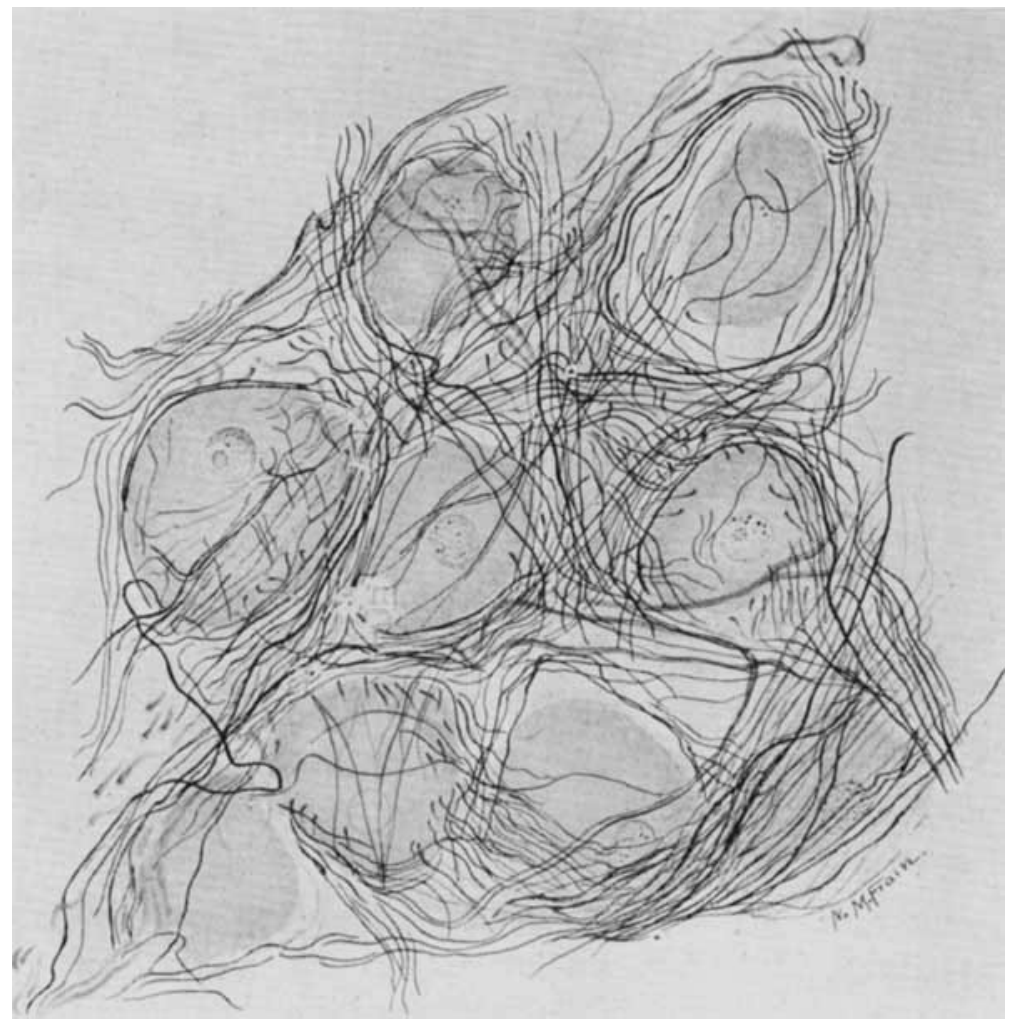

Fig. 10 Intercellular plexus in the ganglion cervioale superius of the dog. Section $20 \mu$. Pyridine silver. $\times 800$.

considerable distances without branching. The majority of the fibers are very fine. They run in and out among the cells, twisting and turning, crossing and recrossing and forming together a dense interlacement. That practically all of these fibers are unmyelinated can be seen at once by comparing such a prepara- 
tion with one stained by osmic acid. In the latter, in place of the dense interlacement of fine fibers just described, one sees only here and there an isolated myelinated fiber. In many parts of the ganglion these are less numcrous than the nerve cells.

So far as we can determine the intercellular plexus is entirely extracapsular. Although some of the fibers wrap themselves about the cells and form what might seem to be pericellular plexuses (fig. 11), these are found not to be in any way separated from the general plexus which fills in the intervening spaces. We believe that these apparently pericellular baskets are really pericapsular and represent merely portions of the general plexus which are in contact with the cell capsules. It is not clear

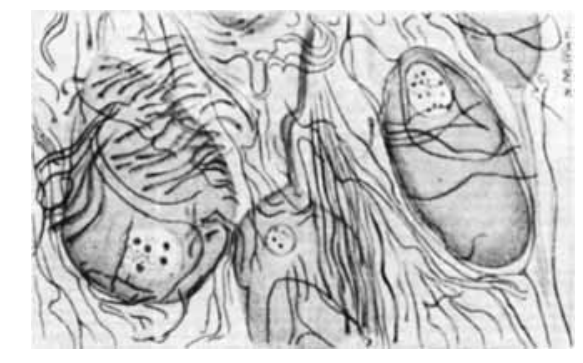

Fig. 11 Three cells from the ganglion cervicale superius of the dog showing fibers of the interceliu ar plexus wrapped about them. These fibers seem to be extracapsular. Pyridine silver. $\times 800$.

whether these formations correspond to the pericapsular nets of Michailow or not. It is evident, however, that they do not correspond to Huber's pericellular plexus which is endocapsular and forms a closed network. That all of the fibers of the intercellular plexus are extracapsular is shown by the examination of sections in which the ganglion cells have shrunken, leaving a cleft between them and their capsule. In such cases the fibers in question always remain in or upon the capsule and never lie on the shrunken cell. An additional point of distinction is found in the fact that the pericellular plexus is a closed network while as we shall see anastamoses do not seem to occur among the fibers under discussion. Furthermore, we have twice seen a fragment 
of a closed network on the surface of a cell which we were inclined to regard as a true pericellular plexus. From all these facts we conclude that the pericellular network is ordinarily not stained in the pyridine silver preparations, but that the axonic constituents of the intercellular plexuses come out with great clearness.

It will be remembered that Michailow regarded the plexus under discussion as forming a true net by means of which all or at least many of the fibers are united together, one neurone being thus united to another. This would mean diffuse conduction in the ganglion, which must then act as a whole. This is directly at variance with what is known of the physiology of the sympathetic ganglia. There is no evidence that diffuse conduction occurs in any of them, and in at least two, the superior cervical and the coccygeal ganglia, Langley ('00a, '04) has been able to show that diffusion does not occur. We will take this up in connection with a discussion of the synapses in the sympathetic ganglia.

Neither Dogiel nor Huber gives the impression that the intercellular plexus is a closed net and we have carefully examined pyridine silver preparations for evidence in this regard. While branching fibers are common, it can usually be seen that a larger fiber is dividing into two smaller ones. The junction of three fibers of the same size as at the nodal point of a net does not seem to occur. Often two fibers could be seen crossing, one immediately over the other, but each retained its individuality and sharp contour. If the plexus were a true network, one should be able to find closed meshes surrounded on all sides by anastamosing fibers-an arrangement which does not seem to occur.

In the pyridine silver preparations of the human superior cervical ganglion the fibers of the intercellular plexus stand out prominently, as is seen in figure 5 . The fibers of this plexus mingle with the branches of the long or extracapsular dendrites. Except that the plexus is not as uniformly distributed throughout the ganglion and is perhaps not quite so dense, it resembles that in the dog. There is, however, one important feature in which the human ganglion differs. Fine axons, apparently continuous 
with those of the intercellular plexus, penetrate into the dendritic glomeruli and the dendritic crowns forming subcapsular plexuses in close relation to the subeapsular dendrites. This is well illustrated in figure 5, a. Cajal has considered these fine darkly staining axons as preganglionic fibers of spinal origin. From what has been said and from the accompanying illustrations it will readily be seen that these fibers are the same as those which form the intercellular plexuses in the superior cervical ganglion of the dog and cat. In a paragraph which follows evidence will be presented to show that these are fibers of spinal origin.

Here and there in this plexus in the superior cervical ganglion of the dog or eat one can see faintly stained yellow axons about the size of the larger dark fibers forming the plexus. In many places these lightly stained axons are united into bundles of parallel fibers which run as straight a course as is possible through the ganglion. These light yellow axons and the bundles into which they unite do not seem to belong to the plexus, although necessarily they run through it. The color contrast between the two kinds of fibers is quite sharp in good preparations, but since all gradations are found the color alone is not sufficient to distinguish them. The light axons are among the largest in the ganglion, are of uniform contour and apparently unbranched. They show a marked tendency to group themselves into bundles of parallel fibers in contrast with the more irregular course of the dark fibers.

Distribution of nerve fibers in the ganglion. In regard to the termination of axons in the sympathetic ganglia, Cajal (11) states that in his first work in this field he described two kinds of terminal arborizations, one set representing the branches of the longitudinal sympathetic fibers arising in neighboring ganglia, the other representing branches given off by fibers from the white rami. That distinction does not seem probable to him any longer because of the results of Langley's experiments and because of the presence of many medullated fibers in the commissural cords which are known to come from the spinal cord (Langley, '03, and Müller, '09). Cajal now believes that the two kinds of terminations belong to spinal motor fibers, distinguished 
only by their course in the sympathetic trunk. One innervates the ganglion to which the ramus brings it. The other runs through two or more ganglia before it terminates.

A study of serial sections through the superior cervical ganglion of the cat stained with osmic acid is instructive. At the lower pole a large bundle of myelinated fibers can be traced into the ganglion from the sympathetic trunk. This comes to lie near the center of the ganglion and breaks up into smaller bundles. Many of the fibers seem to lose their myelin sheaths while still within the smaller bundles. At least this seems to be the best explanation of the fact that the number of myelinated fibers scattered among the ganglion cells is so small.

When the sympathetic trunk is cut and time allowed for degeneration all these bundles of fibers have degenerated. There are, however, still present even in the caudal pole of the ganglion a very few scattered myelinated fibers which have their cells of origin in the ganglion. The number of such fibers increases toward the cephalic pole. Here the myelinated and the more numerous unmyelinated postganglionic fibers accumulate in bundles located especially near the periphery of the ganglion. From the pole large branches representing the internal carotid nerve are given off. Other smaller branches are given off in various places from the ganglion.

The small number of myelinated fibers which are scattered among the ganglion cells in comparison to the number entering and leaving the ganglion would indicate that they run considerable distances in the ganglia as unmyelinated fibers.

In following through a series of sections stained by the pyridine silver technique, one sees that the fine axons entering the ganglion from the sympathetic trunk are all stained a dark brown. Each fiber is surrounded by a thin unstained ring of myelin. This central bundle of the ganglion can be seen to break up into smaller and smaller bundles of dark fibers and the constituent fibers of these smaller bundles can be seen to run into and become a part of the intercellular plexus described in the preceding section.

Following the series toward the cephalic end of the ganglion, one sees bundles of axons collecting especially near the periph- 
ery of the ganglion and these can be followed into its various branches of distribution. These fibers are stained yellow or light brown in contrast to the darker fibers entering by way of the trunk. The staining reaction of these axons is exactly like that of the bundles of 'sympathetic fibers' described in the vagus and its branches by Chase and Ranson ('14) "where they are differentiated from the vagus fibers by their lighter stain." We have repeatedly noticed this characteristic light staining of postganglionic autonomic fibers in the various spinal and cerebral nerves. Here the contrast with the darker unmyelinated fibers of cerebrospinal origin could not easily be overlooked.

It is true that these lightly stained axons run among the cells and therefore through the intercellular plexus, but the great bulk of that plexus is composed of fibers whose staining reaction resembles that of the fibers entering by way of the sympathetic trunk. And the impression is gained by a study of such serial sections that this intercellular plexus is formed by the fibers derived from the trunk, and that the other fibers run through the plexus as directly as possible to their point of exit from the ganglion. Were it not for the difference in the color of the two kinds of axons, however, the impression would undoubtedly be given that the plexus is formed by fibers that stream into the ganglion through all its branches. This is the impression that Dogiel, Huber, and Michailow have gained from the study of methylene blue preparations.

The proof that the intercellular plexus is formed by the ramifications of the preganglionic fibers is furnished by the experiment of cutting the sympathetic trunk in the neck and allowing time for degeneration to take place. Pyridine silver preparations of the superior cervical ganglion in which the preganglionic fibers have degenerated show no trace of an intercellular plexus (fig. 12). Our technique does not stain the finer branches of the dendrites and these do not appear in either the normal or altered ganglia, but the fine axonic ramifications that form the normal network are gone. One can readily recognize small bundles of the lightly staining postganglionic fibers and many such fibers running an isolated course. But these fibers do not coil and 
turn about the cells, and wherever several are grouped together they run parallel to each other in small compact bundles. They do not give in any way the appearance of the intercellular network.

By way of summary we may say that the fine myelinated fibers entering the ganglion through the sympathetic trunk are preganglionic elements and form by their ramifications a complicated intercellular plexus of fine unmyelinated fibers. The other branches of the ganglion consists of many unmyelinated and a few myelinated fibers. These all represent the axons of

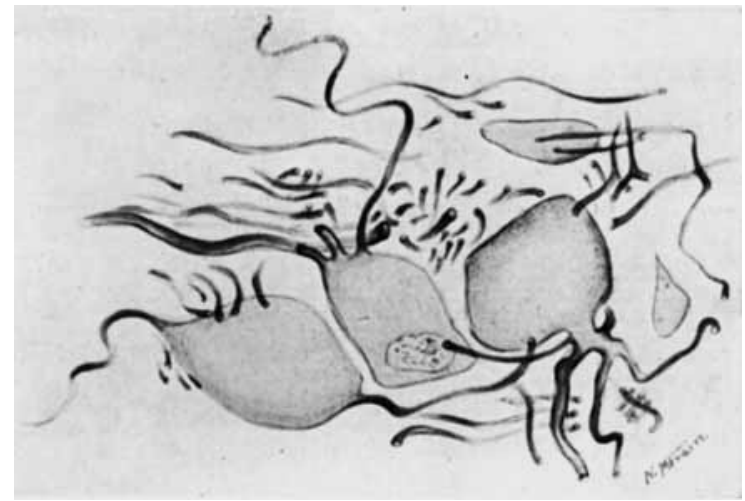

Fig. 12 Three cells from the ganglion cervicale superius of a dog in which the sympathetic trunk had been cut 58 days before the dog was killed. The fine fibers of the intercellular plexus are absent. Pyridine silver. $\times 800$.

the cells in the ganglion and take no part in the formation of the intercellular plexus. They are the postganglionic fibers of Langley.

\section{SYNAPSES IN THE SUPERIOR CERVICAL GANGLION}

Where are the synapses on the paths through the superior cervica ganglion located? Langley ('00), using his method of paralyzing the endings of preganglionic fibers by nicotine, has shown that the fibers of the sympathetic trunk, destined for the superior cervical ganglion, come from the upper thoracic white rami and run without interruption through the upper thoracic ganglia. 
By the same method he has shown that all these fibers end in the superior cervical ganglion. After painting that ganglion with a solution of nicotine no response can be obtained on stimulation of the upper thoracic nerves, showing that all the pathways through the ganglion are blocked. It is generally admitted that this blocking occurs at the synapse. The same effect can be obtained by the intravenous injection of nicotine. Since, however, large doses of nicotine given intravenously will not eliminate the effects of stimulating the internal carotid nerve or other branches of distribution from the ganglion, it is argued that there are no other synapses interposed between this ganglion and the tissues innervated. This conclusion is shown to be correct by the results of the method of degeneration.

That the degeneration, after section of the internal carotid branches, spreads to the periphery, is shown by stimulating the sclerotic before and after degenerative section. In the former case, there is a double effect-local contraction of the radial muscle leading to local enlargement of the pupil, and local contraction of the circular muscle of the iris; in the latter case, the radial contraction is lacking, the circular takes place as before.

The results obtained from section of the sympathetic trunk in the neck and of the internal carotid nerve are all in accord with the conclusions to be deduced from the nicotine experiments.

Our own observations are in full agreement with the conceptions just presented. The trunk consists almost exclusively of medullated fibers, which would not be the case if it contained postganglionic fibers ascending from the thoracic ganglia. All, with the exception of a small bundle of unmyelinated fibers, degenerate in an ascending direction and the degeneration stops in the superior cervical ganglion. The internal carotid nerves are not affected either as to their myelinated or unmyelinated constituents. The conclusion that the only synapses on the functional pathways through the superior cervical ganglion are located in that ganglion is well established. We may now ask what is the nature of the synapses which are to be found there.

Is there a mechanism within the ganglion for the general diffusion of impulses such as occurs in the central nervous system? As a result of the diffusion of impulses in the brain and spinal cord the 
stimulation of a small sensory nerve may bring about reflex activity of the skeletal and involuntary musculature over the entire body. Are impulses disseminated in a similar way in the sympathetic ganglia? Langley ('00) maintains that a preganglionic fiber branches and becomes associated with several postganglionic neurones and that these taken together form a functionally isolated unit. That is to say, there is no general diffusion of impulses through the ganglion. This is beautifully illustrated by his experiments on the pupilodilator pathway.

As pointed out by Hoffmann ('04), the stimulation of a long ciliary nerve causes local dilation of the pupil, while stimulation of the white ramus of either the first or second thoracic nerve causes a general and symmetrical dilation. This might appear to be due to a spreading of the impulses within the superior cervical ganglion to all postganglionic pupilodilator neurones. This is not the case, however, as Langley ('04) has shown: 1) Because stimulation of a small number of postganglionic fibers as they leave the ganglion in any one of the four bundles that form the internal carotid nerve will also cause a symmetrical general dilation. Fibers from such a bundle undergoing rearrangement in the internal carotid plexus are distributed to all parts of the iris. It is therefore unnecessary to assume any spreading out of nerve impulses through diffusion in the ganglion. 2) Local dilation of the pupil can, on the other hand, be obtained by stimulating a few preganglionic fibers in one of the rootlets of the upper thoracic nerves. It is difficult to see how, on any theory of the cells being connected together to form a coördinating center, stimulation of a small number of preganglionic fibers could cause rather marked local dilation of the pupil. The spreading out of the impulses which does occur is due to the intermingling of the postganglionic fibers in the preterminal plexuses.

An even more striking case has been made out against the general diffusion of nerve impulses within sympathetic ganglia in the case of the coccygeal ganglion.

In all compound ganglia it is obvious that stimulation of certain of the preganglionic fibers running to the ganglia excites some only of the nerve cells, and no increase in the strength of the stimulus can cause 
irradiation of nervous impulses to other cells of the ganglion. And the nerve cells which cannot then be brought into action may be nerve cells of the same class as the cells which are in a state of excitation. Of this we may give an example. In the cat, at times, when the arrangement of nerves is posterior, the fourth lumbar nerve causes erection of hairs on the tip of the tail; the nervous impulses pass through nerve eells in the coccygeal ganglion; other nerve cells in the coccygeal ganglia will, on stimulation cause erection of hairs in the greater part of the rest of the tail; but no stimulation of the fourth lumbar nerve will affect this region. Hence, pilomotor nerve cells, set in action by the fourth lumbar nerve, send no commissural fibers to the other pilomotor nerve cells of the coceygeal ganglion. (Langley, '00.)

It thus appears that there is no physiological evidence indicating that diffusion of nerve impulses occurs in the sympathetic ganglia and in certain cases, like those cited, there is positive evidence that diffusion does not occur. We shall now see that there is no histological evidence of any mechanism which could serve to bring about such diffusion.

We may picture such a diffusion mechanism in three ways. The first that suggests itself is a diffuse network formed by anastomosing branches of the preganglionic fibers. Such a network has been assumed by Michailow ('11), but without adequate evidence. In this respect his description of the intercellular plexus does not coincide with that given by Dogiel and Huber. Very clear pictures of the intercellular plexus are obtained in pyridine silver preparations, and these give no indication of anastomosing fibers or of a closed network. The histological evidence is therefore distinctly against the existence of this sort of mechanism for diffusion of nerve impulses.

In the second place, the purpose of diffusion might be served by purely intraganglionic neurones whose axons would branch repeatedly and end within the ganglion. So far as we have been able to find, no one has ever described an axon of a sympathetic ganglion cell as ending within the ganglion where it began. Wherever axons have been traced they have always been seen to leave the ganglion through one or other of its branches. The intercellular plexus of fine fibers, which Dogiel and Huber thought represented the ramifications of such axons, and which, if interrupted in this way, might serve as a mechanism for diffusing 
nerve impulses through the ganglion, we have shown to be formed by the branching of the preganglionic fibers. In a paper which follows, Johnson presents conclusive evidence that commissural neurones do not exist in the ganglia of the sympathetic trunk of the frog.

Finally, diffusion of nerve impulses might occur through collaterals given off by the postganglionic axons before they left the ganglion.

That such collaterals exist has been shown by Dogiel, but we must conclude from his descriptions and figures that they do not occur on the majority of the axons. Michailow does not find them except on the axons of his cells of Type IX. He shows that they end in plates located in the connective tissue of the ganglia between the nerve cells or against the outside of the capsule of a nerve cell. This mode of termination does not speak for them as serving the function of transferring impulses from one neurone to another. In fact, they rather resemble certain collaterals from the axons of spinal ganglion cells which in all probability serve no such function.

The complete absence of fine branching axons in the superior cervical ganglion after degeneration of the preganglionic fibers is strong evidence against the existence of connections between the various cells of the ganglia. In such a ganglion the postganglionic axons can be seen to accumulate in bundles of parallel fibers and run as directly as possible toward the emerging nerves.

From all that has been said we may conclude that there is no physiological or histological evidence for the existence in the superior cervical ganglion of a mechanism for the general diffusion of nerve impulses. And the same conclusion would probably be equally valid for all the ganglia of the sympathetic trunk. We have already discussed the question of commissural fibers joining cells located in adjacent ganglia.

Are there any synapses between sensory and motor neurones within the superior cervical ganglion such as would be required by the conception of the ganglion as a center for visceral reflexes? So far as we have been able to learn, no one has ever described any reflex through this ganglion. According to Langley ('00 a), 
there are no sensory fibers in the cervical sympathetic trunk, since stimulation of this trunk produces no reflex effect through the spinal cord. Since no one has ever claimed that this ganglion contained sensory elements, it is not necessary to discuss this question in detail here. The question of the presence of sensory neurones in the sympathetic ganglia was discussed at some length in the section of this paper dealing with the dendrites. The negative evidence (the absence of fine branching axons in the ganglion after degeneration of the preganglionic fibers) which indicated the absence of connections between the sympathetic ganglion cells would also speak against the existence of sensorymotor synapses.

Synapses between pre-and postganglionic neurones are the only ones of which physiological experiments have given evidence. These are also the only ones that have been demonstrated histologically. The clearest demonstration has been given by Huber ('99) on the frog (fig. 13 and 14). In preparations stained with methylene blue he was able to trace the fibers of the white rami into the trunk ganglia and see them divide repeatedly. Some of these branches he was able to follow to their termination as subcapsular pericellular baskets. In a well stained ganglion it could be seen that the cell body of each neurone was enclosed in such a pericellular plexus. As a rule, the fibrillae of the plexus form a closed network, but now and then fibrillae were found ending free. Similar pericellular plexuses were observed by him in the trunk ganglia of mammals and here again the evidence pointed to their being the endings of fibers from the white rami. These pericellular plexuses have been seen by others, including Ehrlich ('96), Retzius ('89), Arnstein ('87), Aronson ('86), Sala ('93), Van Gehuchten ('92), v. Lenhossék ('94), Dogiel ('95), and Kölliker ('96).

Dogiel ('95) and Huber ('13) could not determine whether all or only a part of the cells of a sympathetic ganglion were surrounded by pericellular plexuses. I take these statements to refer to the mammalian ganglia since Huber ('99) has himself shown that all these cells are so surrounded in the frog. For a full account of this form of synapse the reader is referred to 
Huber's three papers. It seems that the pyridine silver method usually does not stain these pericellular networks; only occasionally have we seen fragmentary impregnations of them. This is in keeping with the fact that the method does not readily yield pictures of nerve endings.

In addition to the pericellular endings thus described there are, we believe, synapses between preganglionic fibers and the dendrites of the cells inthe superior cervical ganglion. This is true

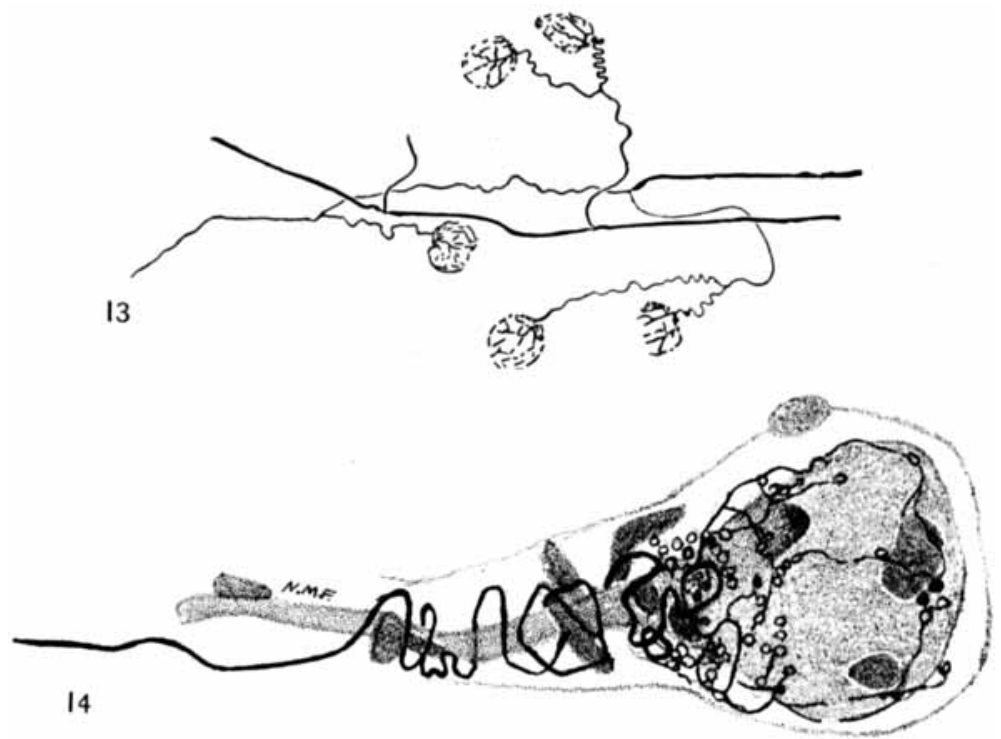

Figs. 13 and 14 Preganglionic fibers and pericellular plexuses of the frog. Redrawn from Huber ('99). The preparations were stained with methylene blue. 13, preganglionic fibers, the branches of which form pericellular plexuses; 14, a sympathetic ganglion cell, unipolar, in connection with which a preganglionic fiber is terminating.

of the subcapsular dendrites in man as well as of the long extracapsular dendrites of man and the dog and cat. As was first shown by Cajal in the superior cervical ganglion of man, the subcapsular dendrites forming glomeruli and dendritic crowns are in close relation to fine, darkly staining fibers, which run among them in every direction. This is illustrated in figure 5 and 6 . These fibers have the same appearance, caliber, and 
staining reaction as the fine fibers of the intercellular plexus in the cat and $\operatorname{dog}$, and they bear the same relation to these subcapsular dendrites that that plexus bears to the extracapsular dendrites. There is every reason to believe that these fibers, like those of the intercellular plexus, are the branches of preganglionic axons. There seems to be no essential difference between the intercellular plexus in man and that which surrounds the subcapsular dendrites except that of location. So far as we are able to judge from our preparations, the intercellular plexus is not so well developed nor so uniformly distributed in man as in the dog. In the cat and dog there are almost no subcapsular dendrites, and so far as we have been able to see the intercellular plexus does not extend beneath the capsule.

We have already given a somewhat extended account of this intercellular plexus and shown that it consists of the ramifications of preganglionic axons. Just what is the relation of the ramifications to the dendritic branches? In pyridine silver preparations the fibers do not seem to end on the dendrites, but rather to form an interlacing feltwork with them. It is probable, however, that here the actual terminations of the axonic ramifications are not stained. In methylene blue preparations Huber ('99) was able to trace some of the fine fibers of the pericellular plexus to their termination on neighboring dendrites.

It seems to be well established that one preganglionic fiber may activate several postganglionic neurones (Langley, '00 b). Histological evidence points to three ways in which this ean be brought about: 1 . The branching of preganglionic fibers, each branch ending in a pericellular basket about a different neurone. The best evidence of this has been given by Huber ('99). Figure 13 is a reproduction of one of his drawings of fibers from a white ramus entering a sympathetic ganglion of the frog. One of these fibers is associated with three pericellular plexuses. This mechanism for bringing several postganglionic neurones under the control of one preganglionic fiber is illustrated diagrammatically in figure $15, b$.

2. The ending of dendrites of one cell in the neighborhood of another cell so as to come under the influence of the axonic ramifications in connection with that cell. This relationship is 
illustrated diagrammatically in figure $15, e$. The ending of dendrites of one cell in the immediate neighborhood of another cell has been observed by a considerable number of investigators. Such endings occur in a variety of different forms which can scarcely be accidental. A dendrite may end by forming a pericellular basket about another cell as seen in figure $8, d$. Such formations have been seen by Cajal ('11), Dogiel ('95),

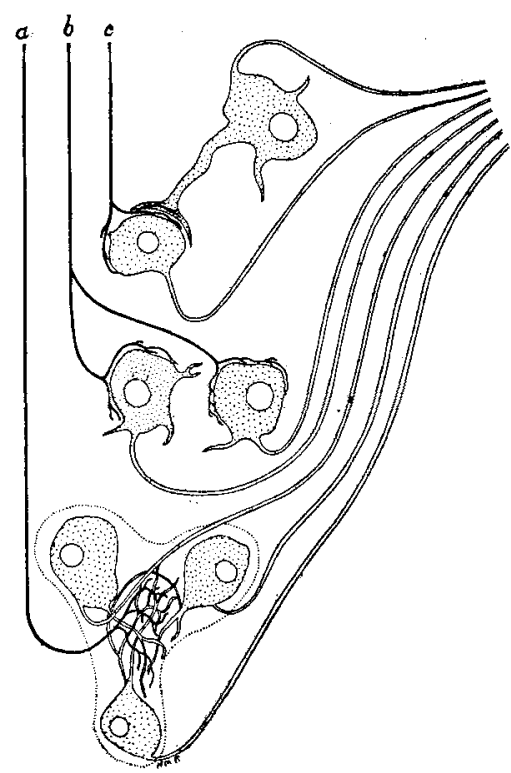

Fig. 15 Diagram illustrating three ways by which one preganglionic fiber may come into relation with two or more postganglionic neurones. a, preganglionic fibers ending in a tricellular glomerulus in connection with the dendrites of three neurons; $b$, a preganglionic fiber branching to form two pericellular plexuses; $c$, a preganglionic fiber ending in connection with the cell body of one neurone and the dendrite of another which is applied to the outer surface of the capsule of the first neurone.

Michailow ('11), and others. According to"Dogiel, such dendritic baskets are always extracapsular. It is obvious that such formations cannot serve to transmit impulses from one sympathetic ganglion cell to another unless we are prepared to admit exceptions to the law of the dynamic polarity of neurones. But even then the capsule would be interposed between the nerve cell and the surrounding dendritic nest. So characteristic an 
arrangement cannot be entirely accidental; and the most obvious functional significance of the dendritic nest would be that the two neurones are thereby in position to be activated by the same preganglionic fiber. This is now Cajal's interpretation of the pericellular dendritic baskets. Such baskets must not be confused with the basket-like appearances produced by dendrites winding their way between the cells without encircling them as has been done by Van Gehuchten and Sala. Functionally similar structures are the plate-like endings of dendrites outside the capsule of another cell as in Michailow's cells of Type III (fig. 8, b) and the smaller egg-shaped endings of the terminal branches of the dendrites of Michailow's Type IV cells which are also applied to the outer surface of the capsule of another cell (fig. 8, $c$ ). We believe that all of these formations are designed to place two neurones under the influence of the same preganglionic fiber as illustrated in figure 15, $c$.

3. Another arrangement of dendrites which seems designed to favor the simultaneous activation of two or more neurones by one preganglionic fiber is found in the bi-, tri-, and multicellular glomeruli in the human superior cervical ganglion. This is illustrated diagrammatically in figure 15, a. Such glomerulae, formed by the dendrites of two or more cells, are numerous in the human ganglion, and one is illustrated in figure 6. A single axon ramifying within such a glomerulus would be in position to activate each neurone contributing dendrites to the glomerulus.

\section{SUMMARY AND CONCLUSIONS}

Although attention is directed in this paper particularly to the cephalic end of the sympathetic trunk and the superior cervical ganglion, the comments drawn from the literature are for the most part applicable to the entire trunk.

A study of the literature based on the evidence obtained by the nicotine and degeneration methods shows that the cephalic end of the sympathetic trunk consists of preganglionic fibers arising in the upper segments of the spinal cord and terminating in the superior cervical ganglion, and that the cells located in this ganglion give rise to fibers which run to terminate in the glands and smooth muscle of the head. 
In fact, the cephalic end of the sympathetic trunk consists almost exclusively of fine medullated fibers, most of which vary in size from $1.5 \mu$ to $3.5 \mu$. These fibers degenerate in an ascending direction after section of the nerve. In pyridine silver preparations no unmyelinated fibers can be distinguished in the normal sympathetic trunk at this level except for some fine branches of distribution from the superior cervical ganglion which happen to be included for a short distance in the same sheath with that nerve. Our observations along with those of Langley show that the superior cervical and stellate ganglia are not connected by myelinated commissural fibers and that unmyelinated commissural fibers if present are very few in number. Physiological experiments conducted by Langley failed to show any evidence of commissural fibers joining these two ganglia. Physiological and histological evidence is also against the presence of afferent fibers in the cervical portion of the trunk.

The nervus caroticus internus in the cat contains, in addition to great numbers of unmyelinated fibers, a very considerable number of fine myelinated fibers, mostly from $1.5 \mu$ to $5.5 \mu$ in diameter. The fibers in this nerve do not degenerate after section of the sympathetic trunk in the neck; all or nearly all of them are postganglionic fibers with their cells located in the superior cervical ganglion.

The dendrites of the cells in the superior cervical ganglion are of two kinds, intracapsular and extracapsular. The intracapsular dendrites are rare in the sympathetic ganglia of mammals but abundant in the human superior ganglion. Here they give rise to the complicated subcapsular formations that have been designated as dendritic crowns and glomeruli. A glomerulus may be formed from the dendrites of a single cell or from those of two or more cells and is designated accordingly as an unicellular, bicellular, tricellular, or multicellular glomerulus.

The extracapsular dendrites are long branched processes which run in every direction among the ganglion cells. In pyridine silver preparations it is not possible to follow them to their true terminations. We have summarized Michailow's account of the termination of these dendrites in preparations stained with methylene blue and illustrated them in figure 8 . The dendrites 
of one cell may form baskets or other special endings about neighboring cells, but these dendritic endings seem to be always outside the capsule of the second cell and therefore could not transmit impulses to it.

Sensory neurones with long dendrites have been described in sympathetic ganglia by Dogiel, but a review of the literature on this point shows that his interpretation of these structures has received little support from the observations of others. It is also doubtful if the axons of cells in the sympathetic ganglia run to spinal ganglia to form baskets about the cells located there.

The axons of sympathetic ganglion cells may acquire myelin sheaths, but usually do not. A study of the literature would indicate that they usually run, without giving off collaterals, into one of the branches of distribution arising from the ganglion. Some run through a connecting nerve to another ganglion, but there is no evidence to show that they ever end there. It would seem more likely that these fibers merely run through this second ganglion to join the nerve to which they are distributed. Some postganglionic fibers give off collaterals either in the original ganglion or in a second ganglion through which they pass, but these collaterals have been shown by Michailow to have endings not well adapted for the transference of nerve impulses.

Between the cells is a rich plexus of fine axonic ramifications which is formed by the branching of the preganglionic fibers. This disappears when the preganglionic fibers degenerate. It is probable that many of the fibers of the intercellular plexus form synapses with the dendrites of the sympathetic ganglion cells.

In pyridine silver preparations of the superior cervical ganglion of the cat it is possible to trace the darkly stained preganglionic fibers from the sympathetic trunk and to see that they undergo repeated branching and take a large part in the formation of the intercellular plexus. The postganglionic fibers, which are more lightly stained, and for the most part devoid of branches, take only a minor part in the formation of this plexus, but become grouped into bundles of parallel fibers which run toward the branches of distribution of the ganglion.

There is no evidence for the existence of synapses, either commissural or sensory-motor, between the neurones located in the 
ganglion and there appears to be no mechanism for a diffusion of incoming nerve impulses to all of the cells nor to all of the cells of a given function within the ganglion.

Evidence furnished by nicotine and degeneration experiments shows that all the synapses between the pre- and post-ganglionic neurones on the pathways through the superior cervical ganglion are located in that ganglion. There are no ascending postganglionic fibers in the cervical portion of the sympathetic trunk and no preganglionic fibers are continued through the superior cervical ganglion into the branches of distribution. The pre-postganglionic synapses seem to be of two kinds: 1) pericellular networks and 2) relations established between the dendrites and axons in the intercellular plexus. One preganglionic fiber activates several post-ganglionic neurones. The dendrites of the postganglionic neurones serve to increase the complexity of these relationships and may aid in bringing two or more neurones under the influence of a single axon as indicated in figure 15.

\section{LITERATURE CITED}

Arnstein, C. 1887 Die Methylenblaufärbung als histologische Methode. Anat. Anz., 2, p. 125.

Aronson 1886 Beitrüge zur Kenntniss der centralen und peripheren Nervenendigungen. Inaugural Dissertation, Berlin, 1886.

Carpenter, F. W., and Conel, J. L. 1914 A study of ganglion cells in the sympathetic nervous system with special reference to intrinsic sensory neurones. Jour. Comp. Neur., vol. 24, pp. 269-281.

Cajal, S. Ramon. 1911 Histologie du système nerveux de l'homme et des vertébrés, vol. 2, p. 891. Paris, 1911.

Chase, M. R., and Ranson, S. W. 1914 The structure of the vagus nerve. Jour. Comp. Neur., vol. 24, p. 31.

Dogiel, A. S. 1895 Zur Frage über den feineren Bau des sympathischen Nervensystems bei den Säugethieren. Arch. f. mikr. Anat., vol. 46, p. 305. 1896 Zwei Arten sympathischer Nervenzellen. Anat. Anz., 11, pp. 679-687.

EnrLich 1886 Ủber die Methylenblaufärbung der lebenden Nervensubstanz. Deutsehe Med. Wochensch., Bd. XII, p. 49.

Hofmans, F. B. 1904 Die neurogene und myogene Theorie der Herzthätigkeit und die Funktion der inneren Herznerven. Schmidt's Jahrb. d. ges. Medicin, Bd. 281, p. 113.

Huber, G. C. 1899 A contribution on the minute anatomy of the sympathetic ganglia of the different classes of vertebrates. Jour. Morph., vol. 16, pp. $27-90$. 
Huber, G. C. 1913 The morphology of the sympathetic system. XVII International Congress of Medicine, London, 1913, Section I, p. 211.

v. Kölliker, A. 1894 Über die feinere Anatomie und die physiologische Bedeutung des sympathetischen Nervensystems. Gesellschaft Deutscher Naturforschen und Aerzte. Verhand. 1894, Allgemeiner Theil.

1896 Handbuch der Gewebelehre des Menschen. Bd. 2, pp. 854-871. Leipzig, 1896.

Kurtz, A. 1913 On the innervation of the digestive tube. Jour. Comp. Neur., vol. 23 , p. 173 .

Langlex, J. N. 1892 On the origin from the spinal cord of the cervical and upper thoracic sympathetic fibers with some observations on white and grey rami communicantes. Phil. Transact. Roy. Soc. Lond., vol. 183, Series B, p. 85 .

1896 Observations on the medullated fibers of the sympathetic system and chiefly on those of the grey rami communicantes. Jour. of Physiol., vol. 20 , p. 55 .

1900 a Remarks on the results of degeneration of the upper thoracic white rami communicantes, chiefly in relation to commissural fibers in the sympathetic system. Jour, of Physiol., vol. 25, p. 468.

$1900 \mathrm{~b}$ The sympathetic and other related systems of nerves. Schäfer's Text-book of Physiology, vol. 2.

1903 The autonomic nervous system. Brain, vol. 26, p. 1.

1904 On the question of commissural fibers between nerve cells having the same function. Jour. of Physiol., vol. 31, p. 244.

v. Lenhossí K, M. 1894 Beiträge zur Histologie des Nervensystems und der Sinnesorgane. Wiesbaden, 1894.

MARINeseo, M. G. 1906 Quelques rechereches sur la morphologie normale et pathologique des cellules des ganglions spinaux et sympathiques de l'homme. Le Névraxe, t. 8, p. 9.

Michatlow, S. 1908 Die Neurofibrillen der sympathischen Ganglienzellen bei Säugetieren. Folia Neuro-biologica, Bd. 1, p. 637.

1911 Der Bau der zentralen sympathischen Ganglien. Internat. Monatschrift f. Anat. u. Physiol., vol. 28, pp. 26-115.

MÜller, R. L. 1909 Studien über die Anatomie und Histologie des sympathischen Grenzstranges insbesondere über seine Beiziehungen zu dem spinalen Nervensysteme. 26. Kongr. innere Med. Wiesbaden, p. 658. Ref. in Jahres. Anat. u. Entwick., 15 III, p. 731.

Retzius, G. 1889 Zur Kenntniss der Ganglien Zellen des Sympathicus. Verhandlungen $\mathrm{d}$. biolog. Vereins in Stockholm. Bd. 2, 1889. Cited after Huber.

SalA, L. 1893 Sur la fine anatomie des ganglions du sympathique. Archiv. Ital. de Biol., vol. 18, p. 439.

Van Gehuchten, A. 1892 Les cellules nerveuses du sympathique chez quelques mammifères et chez l'homme. La Cellule, t. 8.

Waller AND Budge Cited after Langley. 